\title{
Pencegahan Perilaku Menyimpang Akibat Penyalahgunaan Narkoba pada Remaja Millenial di Pulau Untung Jawa
}

\author{
Aulia Nursyifa ${ }^{1}$ \\ ${ }^{1}$ Universitas Pamulang, Indonesia
}

\begin{abstract}
A B S T R A C T
PREVENTION OF DEVIANT BEHAVIOUR DUE TO DRUG ABUSE IN MILLENIAL ADOLESCENTS IN UNTUNG JAWA ISLAND. The changing times are so rapidly that youth are susceptible to deviating behaviors, one of which is drug abuse among adolescents. The existence of tourist attraction becomes an attraction for tourists in Pulau Untung Jawa, the tourists can bring influence to the youth in Untung Jawa island including drug use. The purpose of this devotion is to provide knowledge to the youth to make precautions against deviant behavior due to drug abuse. Method of community devotion in the form of counseling to adolescent youth organization Untung Jawa Island which amounted to 30 people. The results of devotion to the community showed that there was increased understanding of participants related to drug hazards of $82 \%$. The participants were also very enthusiastic to follow the activities that took place. With the activity of devotion to the community can provide awareness for adolescents to do prevention of the impact of the drug by conducting a variety of positive activities such as: following entrepreneurial training, attending sports activities, attending the arts, following religious activities, becoming a janitor, and developing tourism objects in the Untung Jawa Island. This effort is a preventive measure of deviant behaviour due to adolescent drug abuse. The youth of Untung Jawa Island has proved to be a healthy generation without drugs and a young generation that is useful to the surrounding community.
\end{abstract}

\begin{tabular}{llll} 
Keywords: & \multicolumn{1}{c}{ Drugs, Deviant Behaviour, Millennial Adolescents, Prevention. } \\
\hline Received: & Revised: & Accepted: & Available online: \\
19.05 .2020 & 15.08 .2020 & 29.10 .2020 & 30.11 .2020 \\
\hline
\end{tabular}

\section{Suggested citation:}

Nursyifa, A. (2020). Pencegahan perilaku menyimpang akibat penyalahgunaan narkoba pada remaja millenial di Pulau Untung Jawa. Jurnal Pengabdian Pada Masyarakat, 5(4), 1110-1121. https://doi.org/10.30653/002.202054.567

Open Access I URL: http://ppm.ejournal.id/index.php/pengabdian/article/view/567

\footnotetext{
${ }^{1}$ Corresponding Author: Universitas Pamulang; Jl. Surya Kencana No.1, Pamulang Bar., Kec. Pamulang, Kota Tangerang Selatan, Banten 15417, Indonesia. Email: aulianursyifa@unpam.ac.id
} 


\section{PENDAHULUAN}

Dewasa ini para remaja millennial sangat rentan untuk melakukan perilaku menyimpang. Hal tersebut disebabkan karena masa remaja merupakan masa transisi antara anak-anak menuju pendewasaan diri. Pada masa ini para remaja sedang mencari jati diri sehingga cenderung sangat labil, kepribadian yang selalu berubah-ubah, jiwanya masih belum stabil, mudah emosional, mudah stress, salah memilih pergaulan, dan berbagai permasalahan lainnya yang membuat remaja dapat melakukan perbuatan yang menyimpang.

Perilaku menyimpang menjadi kajian khusus dalam Sosiologi, berbagai sosiolog mendefinisikan perilaku menyimpang. Menurut Soekanto (2010: 196) perilaku menyimpang merupakan perilaku akibat kegagalan dalam mematuhi berbagai aturanaturan yang ada dalam kelompoknya. Perilaku menyimpang didefinisikan sebagai perilaku yang tidak sesuai dengan kebiasaan yang ada, adat istiadat, aturan-aturan, serta aturan nilai dan norma yang ada di masyarakat (Kartono, 2009; Setiadi, 2011; Syarbaini dan Rusdiyanta, 2009). Berdasarkan beberapa pengertian tersebut, perilaku menyimpang dianggap sebagai perilaku yang buruk diluar dari kebiasaan masyarakat umumnya, melanggar aturan nilai dan norma sosial yang ada, perilaku menyimpang sebagai wujud dari keadaan disfungsi sosial dari suatu masyarakat.

Perilaku menyimpang yang dilakukan para remaja dapat dikatakan sebagai bentuk dari kenakalan remaja. Kenakalan remaja menurut Kartono (2010) atau yang disebut dengan istilah Juvenile delinquency merupakan perilaku kenakalan yang dilakukan remaja, yang merupakan gejala dari patologi sosial yang disebabkan oleh pengabaian sosial, sehingga mereka melakukan berbagai bentuk perilaku menyimpang. Berdasarkan penelitian yang dilakukan Patinus, et, al (2014) hasil penelitian menunjukkan terjadi peningkatan kenakalan remaja akibat kemajuan teknologi serta menipisnya moral generasi muda. Berbagai wujud perilaku menyimpang dikalangan remaja diantaranya yaitu: kebiasaan merokok, membolos sekolah, tauran pelajar, bullying, perkelahian gang, kebut-kebutan dijalanan, kriminalitas, mabuk-mabukkan, perjudian, seks bebas, kecandun narkoba, dan sebagainya.

Salah satu wujud perilaku menyimpang dikalangan remaja yang akan dibahas adalah terkait dengan perilaku menyimpang akibat penyalahgunaan narkoba. Berdasarkan Undang-Undang RI Nomor 35 Tahun 2009 Pasal 1 Ayat 1 Tentang Narkotika, narkotika adalah zat dari tanaman atau bukan tanaman, baik sintetis maupun semisintetis, yang dapat menyebabkan hilangnya kesadaran, mengurangi nyeri, dan menimbulkan ketergantungan (Kementerian Republik Indonesia, 2009). Narkotika termasuk dalam jenis obat-obatan terlarang yang memiliki zat adiktif atau ketergantungan jika mengkonsumsinya dan dapat merusak jaringan saraf dan gangguan psikomotorik penggunanya (Narwoko dan Suyanto, 2014). Jenis-jenis narkoba diantaranya kokain, ganja, sabu-sabu, ekstasi, morfin, heroin, valium, dan sebagainya.

Berdasarkan data dari World Drugs Reports pada tahun 2018 yang diterbitkan United Nations Office on Drugs and Crime (UNODC) diketahui bahwa sebanyak 275 juta penduduk di dunia pernah menggunakan narkoba (Suara.com, 2019). Sedangkan di Indonesia berdasarkan data dari Badan Narkoba Nasional (BNN) pada tahun 2019 pengguna narkoba di Indonesia mencapai 4.5 juta orang (Jpnn, 2019). Sepanjang tahun 
2019 telah terjadi peningkatan jumlah pengguna narkoba dikalangan remaja millennial dari $20 \%$ menjadi $25 \%$ dari jumlah pengguna narkoba di Indonesia (Tribunnews.com, 2019).

Hasil Survei yang dilakukan Badan Narkoba Nasional (BNN) dan Lembaga Ilmu Pengetahuan Indonesia (LIPI) menunjukkan bahwa terdapat 2,3 juta remaja pernah menggunakan narkoba (CNN Indonesia, 2019). Berdasarkan data tersebut, sangat mengkhawatirkan bahwa Indonesia sedang memasuki darurat narkoba, apalagi narkoba telah mengancam generasi penerus bangsa. Oleh karena itu, perlu adanya upaya untuk melakukan pencegahan dari perilaku menyimpang akibat penyalahgunaan narkoba dikalangan remaja, jangan sampai para remaja menjadi korban dari penyalahgunaan narkoba. Salah satu upaya yang dilakukan untuk mencegah penyalahgunaan narkoba, maka perlu adanya sosialisasi tentang bahaya narkoba.

Sebagai upaya melakukan edukasi kepada masyarakat tentang bahaya narkoba, maka dilakukan kegiatan pengabdian kepada masyarakat di Pulau Untung Jawa Kepulauan Seribu Jakarta. Pulau Untung Jawa menjadi destinasi pariwisata menarik yang ada di ibu kota Jakarta karena jaraknya yang dekat dengan ibukota dan mudah ditempuh, keberadaan wisatawan setiap harinya datang ke pulau ini menjadikan Pulau Untung Jawa sebagai tempat wisata yang diminati khususnya dikalangan generasi muda. Pulau Untung Jawa juga memiliki keistimewaan lainnya yaitu Pulau Untung Jawa sangat tertara rapih, bersih, nyaman, di sepanjang jalan penuh hiasan cat warna warni, banyak tempat yang menarik untuk berfoto, fasilitas dan sarana umum yang lengkap, ditambah lagi penduduknya yang sangat ramah menjadi keunggulan objek wisata ini.

Keberadaan wisatawan menjadi hal yang biasa bagi masyarakat Pulau Untung Jawa, karena dengan adanya wisatawan dapat menambah pendapatan bagi masyarakat sekitar dengan menjual berbagai macam cinderamata maupun jasa penginapan. Disisi lain keberadaan wisatawan mendatangkan dampak positif bagi masyarakat sekitar, namun disisi lainnya wisatawan dapat menjadi sumber permasalahan ketika wisatawan membawa pengaruh negatif bagi masyarakat sekitar seperti dengan adanya penyalahgunaan narkoba di tempat wisata.

Selama ini masyarakat khususnya remaja kurang teredukasi tentang masalah perilaku menyimpang akibat penyalahgunaan narkoba, padahal dengan adanya pengetahuan yang mempuni dapat membentengi diri remaja dari perilaku yang menjurus terhadap perilaku yang menyimpang tersebut. Peredaran narkoba dapat terjadi di daerah wisata seperti Pulau Untung Jawa, oleh karena itu keberadaan objek wisata jangan sampai dicemari dengan keberadaan narkoba di wilayah tersebut sehingga dapat merusak moral generasi muda. Padahal pengetahuan tentang bahaya narkoba bagi masyarakat yang berada di objek wisata sangat penting. Sebagaimana hasil pengabdian kepada masyarakat terkait dengan penyuluhan bahaya narkoba bagi para pemandu wisata dapat menanggulangi penyalahgunaan narkoba dikawasan wisata, sehingga para pemandu wisata dapat memberikan pengetahuan penyalahgunaan narkoba kepada pengunjung (Utami, 2017). Langkah yang demikian dapat diterapkan di tempat wisata lainnya seperti diberikan kepada masyarakat Pulau Untung Jawa, pengetahuan tersebut menjadikan masyarakat sebagai pemandu wisata 
yang memiliki edukasi tentang bahaya narkoba. Hal ini diperkuat berdasarkan hasil wawancara pendahuluan untuk mencari tahu akar permasalahan yang dibutuhkan dari masyarakat Pulau Untung Jawa, dari hasil wawancara ditemukan bahwasanya "belum pernah ada pelatihan sebelumnya terkait dengan bahaya narkoba bagi masyarakat sekitar" (Wawancara Narasumber Is, 2019). Dari penjelasan tersebut menjadikan inspirasi bagi penulis dalam pengabdian kepada masyarakat di Pulau Untung Jawa.

Sebagai upaya untuk mencegah perilaku menyimpang akibat penyalahgunaan narkoba, maka dilakukan kegiatan "Pencegahan Perilaku Menyimpang Akibat Penyalahgunaan Narkoba Pada Remaja Millenial". Kegiatan ini bertujuan untuk memberikan pengetahuan kepada para remaja untuk melakukan pencegahan terhadap perilaku menyimpang akibat penyalahgunaan narkoba. Sosialisasi ini diharapkkan dapat memberikan manfaat terutama bagi generasi millenial agar dapat menjadi generasi penerus bangsa yang sehat tanpa narkoba.

\section{METODE}

Metode yang akan digunakan dalam pengabdian masyarakat ini adalah melalui pendidikan masyarakat berupa penyuluhan kepada masyarakat dengan tujuan dapat meningkatkan pemahaman serta kesadaran masyarakat terutama generasi muda terkait dengan bahaya narkoba yang dapat mengancam nyawa mereka, sehingga pencegahan perilaku menyimpang akibat penyalahgunaan narkoba dapat dilakukan sejak dini. Tempat kegiatan pengabdian kepada masyarakat yang dilakukan di Kelurahan Pulau Untung Jawa, Kecamatan Kepulauan Seribu, Jakarta. Adapun waktu kegiatan pengabdian kepada masyarakat dilakukan pada bulan September sampai November 2019. Adapun sasaran program kegiatan pengabdian masyarakat yaitu 30 orang remaja yang bergabung dalam organisasi karang taruna di Pulau Untung Jawa.

Pengumpulan data selama berlangsungnya kegiatan pengabdian kepada masyarakat meliputi: observasi, tes, dan wawancara. Kegiatan observasi dilakukan untuk mengetahui berbagai permasalahan yang dihadapi oleh masyatakat Pulau Untung Jawa secara langsung dengan melakukan wawancara para remaja di Pulau Untung Jawa. Berdasarkan hasil observasi ditemukan bahwa, masih terdapat remaja yang belum mengetahui tentang narkoba dan dampaknya.

Selanjutnya dilakukan tes dilakukan sebagai alat pengumpulan data untuk membandingkan hasil pretest dengan posttest yang nanti akan mempengaruhi penilaian (Ross \& Morrison, 2004: 1024). Tujuan dilakukan pretest dan posttest yaitu untuk menilai sejauh mana tingkat pengetahuan peserta tentang narkoba, serta mengetahui bagaimana upaya yang dilakukan untuk melakukan pencegahan narkoba yang ada dilingkungan sekitarnya. Sedangkan Wawancara dilakukan kepada para remaja tentang bagaimana cara remaja membentengi diri dari bahaya narkoba di lingkungan sekitarnya sebagai langkah pencegahan terhadap penyalahgunaan narkoba bagi remaja. Berikut tahapan kegiatan pengabdian kepada masyarakat, ditunjukkan dalam Gambar 1. 


\section{Permasalahan Mitra:}

1. Remaja kurang teredukasi tentang masalah perilaku menyimpang akibat penyalahgunaan narkoba.

2. Keberadaan desa wisata memberikan resiko terhadap perilaku menyimpang khususnya penyalahgunaan narkoba.

\section{Penyelesaian Masalah Mitra:}

Penyelesaian masalah mitra dilakukan kegiatan penyuluhan tentang pencegahan perilaku menyimpang akibat penyalahgunaan narkoba.

\section{Tahapan Perencanaan:}

1. Melakukan observasi terkait dengan masalah mitra

2. Perencanaan waktu dan acara kegiatan

3. Perizinan kegiatan

4. Sosialisasi kegiatan

\section{$\checkmark$}

1. Pretest

\section{Tahapan pelaksanaan :}

2. Melakukan pemaparan materi tentang: macam-macam perilaku menyimpang dikalangan remaja, narkoba dengan beragam jenis, penyebab seseorang remaja menggunakan narkoba, dampak dari pengunaan narkoba, berbagai upaya pencegahan terhadap penyalahgunaan narkoba.

3. Melakukan sesi tanya jawab kepada peserta

4. Memutarkan video tentang kasus narkoba yang menjerat remaja

5. Memberikan motivasi kepada peserta bahwa mereka harus menjadi generasi penerus bangsa yang unggul dan sehat bebas dari narkoba.

1. Memberikan posttest

\section{Tahapan Evaluasi:}

2. Melakukan Wawancara

\section{Tindak Lanjut:}

1. Memberikan pendampingan kepada remaja dengan memberikan solusi yang tepat atas berbagai persoalan yang mereka hadapi.

2. Memberikan arahan kepada remaja untuk aktif dalam kegiatan karangtaruna dan selalu melakukan hal positif.

Gambar 1. Tahapan Kegiatan Pengabdian kepada Masyarakat Sumber: Data penulis, 2019 


\section{HASIL DAN PEMBAHASAN}

Hasil pengabdian kepada masyarakat di Pulau Untung Jawa berjalan sesuai dengan yang telah direncanakan bersama. Kegiatan pengabdian kepada masyarakat ini memberikan banyak manfaat bukan hanya bagi masyarakat Pulau Untung Jawa tetapi juga bermanfaat bagi dosen pengabdi terutama mahasiswa untuk mengimplementasikan keilmuan yang dimiliki di Perguruan Tinggi direalisasikan kepada masyarakat. Realisasi pemecahan masalah yang dilakukan oleh tim pengabdian dilakukan berjalan lancar yang dimulai dari kegiatan observasi sampai dengan kegiatan evaluasi dari pelaksanaan pangabdian kepada masyarakat. Observasi yang dilakukan kepada masyarakat yang berusaha menggali informasi tentang permasalahan maupun kebutuhan masyarakat. Masyarakat Pulau Untung Jawa memiliki kekhawatiran tentang pergaulan remaja yang terjadi saat ini, dengan banyaknya wisatawan ke Pulau Untung Jawa membawa pengaruh pada elemen kehidupan masyarakat terutama dikalangan remaja, apalagi dengan karakteristik remaja di Pulau Untung yang tidak semua mendapatkan jenjang pendidikan sampai tinggi, hal itu dikarenakan akses daerah yang berada di kepulauan, sehingga sekolah-sekolah menengah maupun perguruan tinggi harus mereka tempuh dengan jarak yang jauh. Remaja di kepulauan Untung Jawa kebanyakan diarahkan bekerja di sector pariwisata. Meskipun para remaja tidak mengenyam pendidikan tinggi secara formal, namun pendidikan masyarakat tetap sangat dibutuhkan bagi para remaja, karena mereka perlu dibina dan diarahkan agar selalu melakukan hal positif dan dapat meminimalisir dari berbagai perbuatan yang negatif.

Penyuluhan tentang bahaya narkoba baru pertama diadakan bagi remaja Pulau Untung Jawa, sehingga upaya untuk memberikan edukasi kepada remaja Pulau Untung Jawa terkait dengan pencegahan penyalahgunaan narkoba sangatlah penting. Adapun tema-tema yang diangkat dalam pengabdian ini diantaranya yaitu: penyuluhan tentang macam-macam perilaku menyimpang dikalangan remaja, narkoba dengan beragam jenis, penyebab seseorang remaja menggunakan narkoba, dampak dari pengunaan narkoba, berbagai upaya pencegahan terhadap penyalahgunaan narkoba, melakukan sesi tanya jawab kepada peserta terkait dengan penyalahgunaan narkoba, memberikan motivasi kepada peserta bahwa mereka harus menjadi generasi penerus bangsa yang unggul dan sehat bebas dari narkoba, memberikan diskusi tentang berbagai persoalan terkait dengan problematika yang terjadi dikalangan remaja, memutarkan beragam contoh video tentang kasus narkoba yang menjerat remaja, dengan video tersebut para remaja memiliki kesadaran karena dampak yang ditimbulkan dari penyalahgunaan narkoba sangat besar bagi hidup remaja, memberikan pendampingan kepada remaja dengan memberikan solusi yang tepa tatas berbagai persoalan yang mereka hadapi. Memberikan arahan kepada remaja untuk aktif dalam kegiatan karangtaruna dan selalu melakukan hal positif. Berbagai kegiatan yang telah dilakukan pada masyarakat di Pulau Untung Jawa ini terlaksana dengan baik. Hal ini menandakan bahwa realisasi dari Tridarma Perguruan Tinggi yang dilakukan dosen pengabdi dapat bermanfaat bagi masyarakat sekitar khususnya bagi remaja Pulau Untung Jawa. 
Dalam rangka mengetahui tingkat pemahaman peserta pengabdian kepada masyarakat di Pulau Untung Jawa terkait dengan tema pengabdian yaitu tentang narkoba, maka tim dosen pengabdi memberikan ujian berupa pre test dan post test kepada para peserta. Hasil pre test dan post tes sebagai berikut.

Tabel 1. Hasil Tes Pemahaman Remaja Terkait Narkoba
\begin{tabular}{ll}
\hline Hasil tes & \\
\hline Pre Test & Post Test \\
$46 \%$ & $82 \%$ \\
\hline
\end{tabular}

Tabel 1 menunjukkan hasil tes pemahaman peserta tentang narkoba. Pre test diberikan kepada peserta sebelum mereka mengikuti kegiatan pengabdian kepada masyarakat, tujuan dilakukan pre test yaitu untuk mengukur tingkat pemahaman remaja Pulau Untung Jawa terkait dengan narkoba, hasil pre test didapatkan hanya $46 \%$ yang dapat memahami terkait dengan narkoba. Sedangkan hasil post tes diberikan kepada peserta pelatihan setelah mereka mengikuti berbagai kegiatan pengabdian kepada masyarakat dan hasilnya menunjukkan adanya peningkatan kemampuan peserta dalam memahami tentang narkoba sebesar $82 \%$, berarti ada kenaikan pemahaman sekitar $36 \%$ kepada peserta pelatihan.

Keberhasilan kegiatan pengabdian kepada masyarakat juga dapat dilihat tingkat antusias yang tinggi dari para remaja Pulau Untung Jawa untuk mengikuti berbagai kegiatan yang dilakukan oleh tim pengabdi. Selain itu, antusiasme peserta juga dapat dilihat dari tingginya angka partisipasi peserta pada setiap kegiatan dalam mengajukan berbagai pertanyaan kepada narasumber.

Masa remaja disebut masa yang paling rawan dihadapi individu. Massa remaja merupakan peralihan dari anak menuju ke dewasa, remaja millenial akan mengalami perkembangan secara fisik maupun psikis dengan berbagai perubahan. Apalagi dengan adanya kemajuan informasi dan teknologi membuat remaja mellenial akan mudah menyerap budaya luar yang tidak sesuai dengan nilai-nilai budaya bangsa termasuk gaya hidup yang negatif dengan menggunakan narkoba. Peredaran dan penyalahgunaan Narkoba merupakan salah satu permasalahan nasional yang dipandang serius oleh pemerintah maupun masyarakat, karena penyimpangan tersebut dapat menyebabkan rusaknya moral generasi penerus bangsa. Karena itu pemerintah sangat memberikan perhatian terhadap penanganan atas penyalahgunaan Narkoba, serta yang paling penting dalam upaya pencegahan terhadap narkoba adalah peran orang tua maupun masyarakat dalam melakukan kontrol sosial bagi para remaja agar terhindar dari penyalahgunaan narkoba sehingga dapat menjadi remaja yang bermoral dan beradab.

Pencegahan penyalahgunaan narkoba di Pulau Untung Jawa dapat dilakukan dengan berbagai cara. Pencegahan penyalahgunaan narkoba dikalangan remaja efektif dilakukan sejak dini saat anak berada dalam pengasuhan orangtua. Oleh karena itu, peran kontrol sosial yang pertama bagi seorang anak terletak pada lembaga keluarga. Berdasarkan hasil penelitian pecegahan penyalahgunaan narkoba berbasis keluarga sangat efektif dilakukan dengan cara melakukan hubungan baik dengan keluarga, memotivasi untuk masa depan anak, melakukan pengawasan terhadap anak, serta 
selalu memberikan solusi terhadap pemecahan masalah anak (Ryzin, Roseth, Fosco, Lee, \& Chen, 2016).

Melakukan program pembinaan kepada generasi muda yang belum pernah menggunakan narkoba dan belum mengetahui sama sekali tentang seluk beluk narkoba, dengan program pembinaan yang dilakukan secara berkelanjutan diharapkan menambah pengetahuan remaja terhadap bahaya narkoba, dengan begitu remaja dapat melepaskan diri dari jerat narkoba yang ada dilingkungan sekitarnya. Misalnya dalam kegiatan karang taruna diagendakan untuk melakukan sosialisasi tentang penyalahgunaan narkoba dari akademisi, sosiolog, tenaga medis, kepolisian, Badan Narkotika Nasional (BNN), dan sebagainya. Salah satu upaya otentik yang dapat dilakukan pengabdi sebagai akademisi untuk memberikan pembinaan secara langsung kepada remaja di Pulau Untung Jawa. Gambar 2 dokumentasi kegiatan penyuluhan yang dilakukan dosen pengabdi sebagai upaya pencegahan penyalahgunaan narkoba dikalangan pemuda karang taruna di Pulau Untung Jawa:

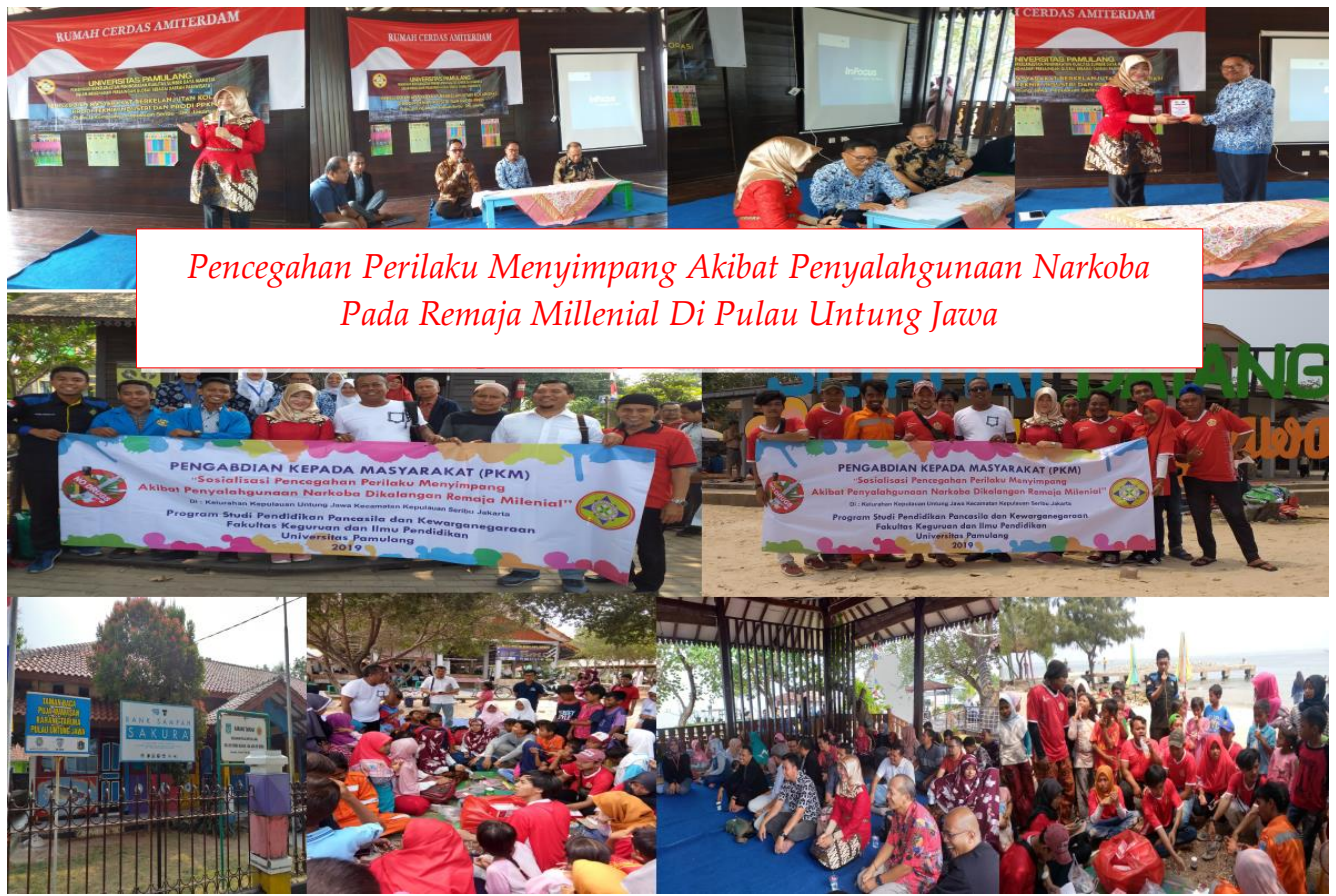

Gambar 2. Kegiatan Pengabdian kepada Masyarakat

Sumber: Dokumentasi Penulis, 2019

Upaya pencegahan perilaku menyimpang dikalangan remaja dapat dilakukan dengan berbagai cara. Salah satunya dengan cara meningkatkan kesejahteraan masyarakat terutama remaja dengan melakukan pelatihan keterampilan bagi remaja, karena pada dasarnya dengan adanya kesejahteraan akan membuat remaja lebih produktif sehingga tidak ada akan mencari jalan kebahagiaan dengan menggunakan narkoba. Sebagaimana diungkapkan dalam hasil penelitian Malla (2019) bahwa kemiskinan dapat menjadi salah satu faktor remaja untuk rentan terhadap terjerumus sebagai pecandu narkoba. Oleh karena itu, sangat penting upaya pencegahan penyalahgunaan narkoba dengan meningkatkan kesejahteraan masyarakatnya khususnya generasi muda. Berbagai upaya untuk meningkatkan kesejahteraan 
masyarakat dengan cara : membuat pelatihan keterampilan dalam berwirausaha bagi remaja, membuat cinderamata sebagai buah tangan wisatawan, serta menumbuh kreativitas remaja dalam memanfaatkan berbagai potensi wisata, bahkan ada sebagian remaja yang bekerja di objek wisata Pulau Untung Jawa baik sebagai petugas kebersihan maupun pekerjaan di sektor pariwisata.

Menggalakkan kampanye anti narkoba dengan tujuan memberikan edukasi kepada masyarakat maupun remaja amat penting untuk menghindari dari penyalahgunaan narkoba yang dituangkan dalam bentuk gambar, karikatur, poster, dan sebagainya. Remaja dapat mengeksplor kreativitasnya lewat gambar-gambar yang menarik tentang pencegahan narkoba. Meningkatkan produktivitas secara positif dengan mengisi waktu dengan berbagai kegiatan seperti: mengikuti kegiatan ta'lim atau pengajian remaja yang diselenggarakan di Pulau Untung Jawa sebagai upaya untuk mendekatkan diri pada Tuhan sehingga dapat menghindari dari perbuatan buruk, penyaluran bakat remaja lewat berkesenian, melakukan aktivitas yang dapat menyehatkan raga dengan rutinitas olahraga, dan sebagainya.

Kerjasama semua pihak dalam menganggulangi pecegahan narkoba di lingkungan masyarakat sangat penting. Kontrol sosial yang dapat dilakukan oleh orantua, tokoh masyarakat, tokoh agama, maupun masyarakat pada umum dalam melakukan pengendalian secara preventif maupun represif penyalahgunaan narkoba di lingkungan sekitarnya. Kepekaan masyarakat menjadi alat kontrol sosial efektif dalam mencegah penyalahgunaan narkoba.

Dari hasil kegiatan pengabdian ini juga terbukti efektif dalam memberikan pengetahuan kepada remaja di Pulau Untung Jawa untuk mengenal berbagai pencegahan dari penyalahgunaan narkoba. Penelitian yang dilakukan Hidayati dan Indrawati (2012) hasilnya menunjukkan sebagian responden memiliki pengetahuan yang tinggi terhadap penyalahgunaan narkoba dan memiliki upaya yang baik untuk melakukan pencegahan terhadap narkoba. Serupa dengan penelitian yang dilakukan bahwa adanya peningkatan pengetahuan remaja setelah dilakukan penyuluhan tentang bahaya narkoba (Anggraeni ,2016 ; Wiyani, Yudiernawati, \& Maemunah, 2017) Hasil penelitian lainnya menunjukkan terdapat pengaruh signifikan antara pemberian bimbingan atau penyuluhan untuk memberikan informasi tentang bahaya narkoba dengan upaya pencegahan penyalahgunaan narkoba (Fitriana, 2011; Fatchurahman \& Bulkani, 2006).

Adapun hasil pengabdian kepada masyarakat tentang penyuluhan narkoba yang dirangkum dari beberapa hasil pengabdian kepada masyarakat maka didapatkan hasilnya bahwa dengan adanya penyuluhan dapat menigkatkan pemahaman serta peningkatan kesadaran tentang penyalahgunaan narkoba (Abudi \& Irwan, 2015; Fitri \& Migunani, 2014; Nurhafni, 2015; Sholihah, 2015). Serupa dengan hasil pengabdian yang dilakukan oleh Hermawan \& Santoso (2013) kegiatan pengabdian tentang penyuluhan bahaya narkoba dapat menekan perilaku negatif remaja sejak dini untuk berkomitmen tidak menggunakan narkoba dikemudian hari. Berdasarkan hasil penelitian dan pengabdian kepada masayarakat tersebut, berbagai upaya telah dilakukan dalam memberikan edukasi kepada masyarakat khsususnya generasi muda tentang bahaya penyalahgunaan narkoba sehingga diharapkan masyarakat dapat mencegah perilaku menyimpang di lingkungan sekitarnya. 
Manfaat yang dirasakan peserta dalam kegiatan pengabdian kepada masyarakat dapat dibuktikan dari hasil wawancara kepada para remaja, "kegiatan pengabdian masyarakat sangat bermanfaat karena dapat menambah wawasan dan menumbuhkan kesadaran akan bahaya narkoba serta selalu menjaga diri untuk tidak melakukan perilaku menyimpang lainnya" (Wawancara dengan Aa, 2019). Berdasarkan kutipan wawancara tersebut dapat menunjukkan bahwa pengabdian kepada masyarakat sangat berguna bagi remaja di Pulau Untung Jawa. Dalam upaya menciptakan generasi sehat tanpa narkoba dapat terealisasi dengan upaya berbagai pihak seperti orangtua, masyarakat, sekolah, kepolisian, tenaga medis, pemerintah daerah setempat untuk bekerjasama dalam memberantas penyalahgunaan narkoba di lingkungan masyarakat sekitar khususnya generasi muda sebagai ujung tombak untuk melanjutkan estafet bangsa.

\section{SIMPULAN}

Kegiatan pengabdian kepada masyarakat ini memberikan kesadaran bagi remaja untuk melakukan pencegahan dari dampak narkoba dengan melakukan berbagai kegiatan yang positif diantaranya aktif dalam Karang Taruna, mengikuti pelatihan wirausaha, mengikuti kegiatan olahraga, mengembangkan objek pariwisata di Pulau Untung Jawa, mengikuti pengajian, kesenian, ada sebagian remaja yang bekerja sebagai petugas kebersihan, dan remaja berupaya untuk mengembangkan objek pariwisata di Pulau Untung Jawa. Upaya ini sebagai langkah pencegahan dari perilaku menyimpang akibat penyalahgunaan narkoba di kalangan remaja. Pemuda di Pulau Untung Jawa telah membuktikan menjadi generasi sehat tanpa narkoba dan menjadi generasi muda yang berguna bagi masyarakat sekitar.

\section{Ucapan Terima Kasih}

Terselenggaranya kegiatan pengabdian ini tidak bisa dilepaskan atas kerjasama semua pihak. Maka dari itu, penulis ucapkan terimakasih kepada Ketua Program Studi Pendidikan Pancasila dan Kewarganegaraan, Dekan Fakultas Keguruan dan Ilmu Pendidikan, Ketua Lembaga Penelitian dan Pengabdian Kepada Masyarakat, Rektor Universitas Pamulang. Terimakasih kepada para dosen dan mahasiswa yang terlibat dalam pengabdian kepada masyarakat. Terimakasih kepada mitra pengabdian Kelurahan Pulau Untung Jawa Kepulauan Seribu Jakarta.

\section{REFERENSI}

Abudi, R., \& Irwan. (2015). Peningkatan pemahaman tentang pencegahan dan penanggulangan narkoba dan HIV AIDS melalui pelatihan kader pada remaja Gorontalo. Gorontalo: Universitas Negeri Gorontalo.

Anggraeni, S. (2016). Efektivitas penyuluhan NAPZA terhadap tingkat pengetahuan siswa di SMK DD Kabupaten Tanah Laut. Jurkesisa, 6(3), 18-22. 
CNN Indonesia. (2019). Survei BNN: 2,3 juta pelajar konsumsi narkoba. Retrieved September 1, 2019, from https://www.cnni.ndonesia.com/nasional./2019062-20405549

Fatchurahman, M. F., \& Bulkani. (2006). Peran guru pembimbing dalam upaya pencegahan penyalahgunaan narkotika pada siswa SMA negeri dan swasta Kota Palangka Raya. Jurnal Warta, 9(1), 21 -27.

Fitri, M., \& Migunani, S (2014). Sosialisasi dan penyuluhan narkoba. Asian Journal of Innovation and Entrepreneurship, 3(2), 72-76.

Fitriana, S. (2011). Kontribusi layanan informasi dan bimbingan kelompok terhadap sikap siswa tentang narkoba. Jurnal Penelitian Psikologi Pendidikan dan Bimbingan (JP3B), 1(1), 1-20.

Hawari, D. (2009). Penyalahgunaan ketergantungan Naza (Narkotika, alkohol dan bahan adiktif). Jakarta: FKUI.

Hermawan, A., \& Santoso, D. W. (2013). Penyuluhan dan Pengenalan Bahaya Narkoba sebagai Bentuk Pencegahan Dini Penggunaan Narkoba pada Anak. Jurnal Inovasi Dan Kewirausahaan, 2(3), 178-182.

Hidayati, P. E., \&.Indrawati. (2012). Gambaran pengetahuan.dan.upaya pencegahan terhadap penyalahgunaan narkoba pada remaja. Jurnal Gaster, 9(1), 15-21.

JPNN. (2019). Ada 4,5 juta pengguna narkoba di indonesia, sikat pengedar dan bandar yang berkeliaran. Retrieved September 1, 2019, from https.://www.jpnn.com/news/ada45juta penggunanarkobadiindonesia.

Kartono, K. (2009). Patologi sosial. Jakarta: Rajawali Pers.

Kartono, K. (2010). Kenakalan remaja. Jakarta: Rajawali Pers.

Kementerian Republik Indonesia. Undang-.Undang Nomor 35 Tahun 2009 Tentang Narkoba (2009). Diambil dari www.hukumonline.com

Malla, M. A. (2019). Factors contributing to the problem of drug abuse among the adolescents in Kashmir Valley. International Journal of Research and Analytical Reviews, 6(1), 248-254.

Narwoko, J. D., \& Suyanto, B. (2014). Sosiologi teks pengantar dan terapan. Jakarta: Kencana.

Patinus, Parwadi, R., \& Donatianus. (2014). Kenakalan remaja di kalangan siswa siswi SMPN 07 Sengah Temila. Jurnal Program Magister Ilmu Sosial. Universitas Tanjungpura, $1-15$.

Ross, S. M., \& Morrison, G. R. (2004). Experimental research methods. In D. H. Jonassen (Ed.), Handbook of Research on Educational Communications and Technology (pp. 10211044). Oxfordshire, United Kingdom: Taylor \& Francis.

Sholihah, Q. (2015). Efektivitas program P4GN terhadap. pencegahan penyalahgunaan Napza. Jurnal Kesehatan. Masyarakat, 9(1), 153-159. 
Setiadi, E. M., \& Kolip, U. (2011). Pengantar sosiologi pemahaman fakta dan gejala permasalahan sosial: Teori, aplikasi, dan pemecahannya. Jakarta: Kencana.

Soekanto, S. (2010). Sosiologi suatu pengantar. Jakarta: Grafindo.

Sunarto, K. (2004). Pengantar sosiologi. Jakarta: Penerbit Fakultas Ekonomi Universitas Indonesia.

Syarbaini, S., \&.Rusdiyanta. (2009). Dasar-dasar sosiologi. Yogyakarta: Graha Ilmu.

Suara.com. (2019). Peningkatan penggunaan narkoba di kalangan remaja di Indonesia mencapai 24 hingga 28 persen. Retrieved September 1, 2019, from https://www.suara.com/news/ 2019/26/132536

Tribunnews.com. (2019). Pengguna narkoba di kalangan. millenial. meningkat. Retrieved September 1, 2019, from https://www.tribunnews.com/nasional/2019/06/26

Utami, H. (2017). Pengembangan wawasan mengenai jenis dan bahaya penyalahgunaan narkoba bagi para pemandu wisata lokal di kawasan wisata Kota Tua Jakarta. Sarwahita, 14(2), 99-107.

Van Ryzin, M. J., Roseth, C. J., Fosco, G. M., Lee, Y. K., \& Chen, I. C. (2016). A componentcentered meta-analysis of family-based prevention programs for adolescent substance use. Clinical Psychology Review, 45, 72-80.

Wiyani, R., Yudiernawati, A., \& Maemunah, N. (2017). Pengaruh pemberian penyuluhan terhadap pengetahuan pada remaja awal tentang bahaya narkoba di MAN 1 Kelas X Malang. Nursing News, 2(2), 772-782.

\section{Copyright and License}

This is an open access article distributed under the terms of the Creative Commons Attribution 4.0 International License, which permits unrestricted use, distribution, and reproduction in any medium, provided the original work is properly cited. (C) 2020 Aulia Nursyifa. 